ppi $201502 Z U 4645$

Esta publicación científica en formato digital es continuidad de la revista impresa ISSN-Versión Impresa 0798-1406 / ISSN-Versión on line 2542-3185Depósito legal pp $197402 Z$ U34

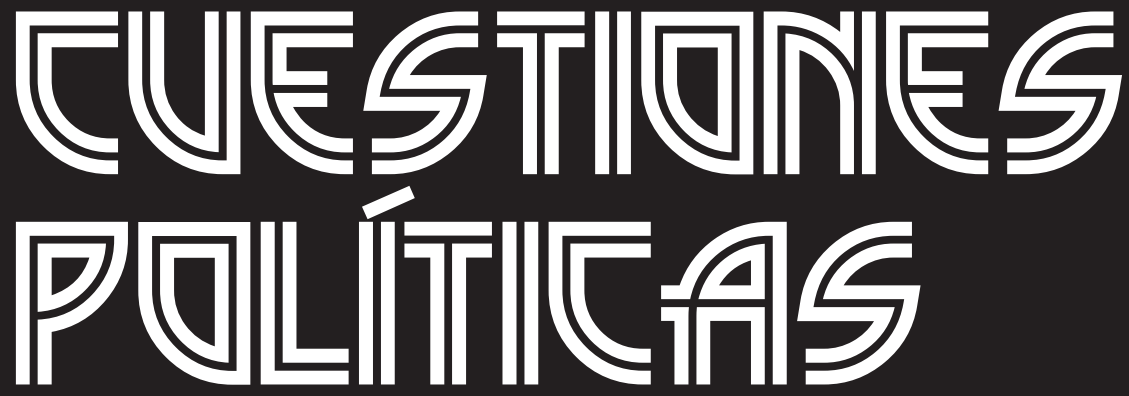

Instituto de Estudios Políticos y Derecho Público "Dr. Humberto J. La Roche" de la Facultad de Ciencias Jurídicas y Políticas de la Universidad del Zulia Maracaibo, Venezuela
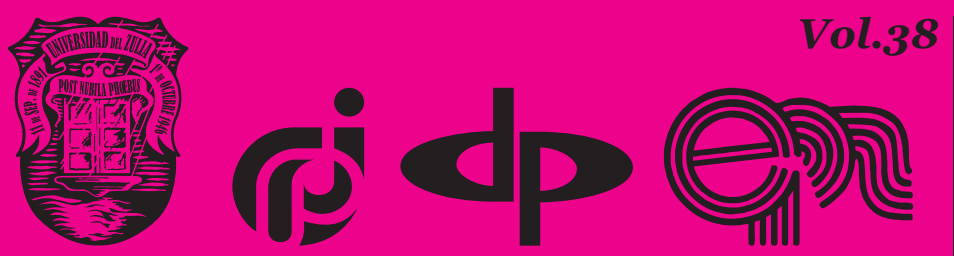

$N^{\circ}$ Especial 1era Parte 2020 


\title{
Economic and Political Realities and Models of Territorial Structure Development in the South of the Far East
}

\author{
DOI: https://doi.org/10.46398/cuestpol.38e.o3
}

\author{
Elena S. Koshevaya * \\ Tatyana K. Miroshnikova **
}

\begin{abstract}
The economic and political processes taking place in the southern Far East have had a significant impact on the development of the territorial structure. Methodologically, a constructive and comprehensive geopolitical approach was used that allowed a structural evaluation of economic and political realities and their impact on the formation and development of the territorial structure, as well as its various orientations and typologies in the south of the country. Far East. In addition, its focused study allowed to evaluate the economic and political effect of the modernization scenario, to analyze the impact of external and internal economic, political and social realities with a focus on the restructuring and organization of the territorial structure, all of which allowed to identify the main problems of its destabilization and, at the same time, determine the prospects for further growth of the elements of the system to varying degrees, affecting the industrial, transportation, infrastructure and other spheres of the population's life. It is concluded that the dialectical interaction of a set of political and economic realities of transformations and modernizations, internal and external, have configured an arial-nodal / linear-nodal polycentric linear structure in the south of the Far East.
\end{abstract}

Keywords: territorial structure; economic and political effect; government scenario; southern Far East, development models.

Associate professor, Vladivostok state university of economics and service, Vladivostok 690014, Russia. Tel.: +79242426142; ORCID ID: https://orcid.org/oooo-ooo2-6994-7177. Email: Elenakh1981@ yandex.ru

$2 * *$ Associate professor, Vladivostok state university of economics and service, Vladivostok 690014 Russia. ORCID ID: https://orcid.org/oooo-00o1-9038-3145. Email: tanmir12@mail.ru 
Elena S. Koshevaya, Tatyana K. Miroshnikova

Economic and Political Realities and Models of Territorial Structure Development in the South

\section{Realidades económicas y políticas y modelos de desarrollo de estructuras territoriales en el sur del Lejano Oriente}

\section{Resumen}

Los procesos económicos y políticos que tienen lugar en el sur del Lejano Oriente han tenido un impacto significativo en el desarrollo de la estructura territorial. En lo metodológico se empleó un enfoque constructivo e integral de tipo geopolítico que permitió una evaluación estructural de las realidades económicas y políticas y de su impacto en la formación y desarrollo de la estructura territorial, así como de sus diversas orientaciones y tipologías en el sur del Lejano Oriente. Además, su estudio focalizado consintió evaluar el efecto económico y político del escenario de la modernización, para analizar el impacto de las realidades económicas, políticas y sociales externas e internas con un enfoque en la reestructuración y organización del estructura territorial, todo lo cual permitió identificar los principales problemas de su desestabilización y, al mismo tiempo, determinar las perspectivas de un mayor crecimiento de los elementos del sistema en diversos grados, afectando las esferas industrial, de transporte, infraestructura y otras esferas de la vida de la población. Se concluye que la interacción dialéctica de un conjunto de realidades políticas y económicas de transformaciones y modernizaciones, internas y externas, han configurado una estructura lineal policéntrica arial-nodal/ lineal-nodal en el sur del Lejano Oriente.

Palabras clave: estructura territorial; efecto económico y político; escenario de gobierno; sur del Lejano Oriente, modelos de desarrollo.

\section{Introduction}

The analysis of the past scenario of the development and the development of the territory in the south of the Russian Far East is represented by its consistent inclusion in the political and economic structure of the state. The economic and political effect of the military-administrative, raw material and integration development and settlement of this territory by Russia shows the government desire to strengthen its presence in the region, using the development of the territorial structure elements as the means of consolidation and attraction. This process is "characterized by continuity in time" (Shinkovsky et al., 2007). It is a holistic system that caused or (assumed) certain changes (Shvedov, 2006) in the economic and political situation proceeding within the framework of the spatial-temporal dynamics. According to (Zausaev et al., 1995), the formation of a support frame here was an integral part of the economic and political strategy of Russia. 


\section{Methods and materials}

A constructive, comprehensive approach to this goal achievement provides for a structural assessment of economic and political realities and their impact on the formation and development of the territorial structure and its elements of various orientations and typology in the south of the Far East. Analysis of the past and current scenario of the system and its polycentric model formation of the frame structure will determine the possibilities and prospects for the development of industrial enterprises of state importance, will analyze the impact of economic and political determinants in the space-time continuum. The studies of the government scenario for a territorial structure and its support frame development are aimed at the retrospective of the past evaluation in order to solve the problems and prospects of economic growth in the south of the region in the future during development and implementation of the programs for innovative, and technological development and economic modernization.

Description of the main provisions for creating the models of territorial structure development

The government scenario for the development of the Far East south is the only possible option to prevent invasiveness and to include it in the integral socio-economic and political structure of the Russian state. This action was accompanied by the creation of new structural elements, the pace of formation of which was associated with the development of internal and external political and economic realities. Thus, the nature of the state internal content formalization through the construction and placement of the territorial structure elements was completely subordinated to state policy and "is performed under the influence of political determinants" (Shvedov, 2006:74).

The government sends the Cossacks to ensure the inviolability of state borders and the formation of the main types of agricultural production in the south of the Far East. The development of this territory by them began with the formation and development of the territorial structure nodal elements, which are the centers (focuses): forts, winter huts, military posts endowed with military-administrative functions. Their organization and construction had a "strictly established order by the Russian administration" with rare exceptions (Artemev, 1998:140).

It was characterized by the location of focus centers along the Amur River, at a certain distance from each other, which indicated militaryadministrative colonization. Here, a linear model of the frame structure has developed, characterized by an elongated system of the territorial structure nodal element placement along the Amur River. Further formation of the territorial structure continued in the depths of the region 
Elena S. Koshevaya, Tatyana K. Miroshnikova

Economic and Political Realities and Models of Territorial Structure Development in the South 66 of the Far East

and was accompanied by the creation of key elements of the economic and industrial orientation: rural and working settlements (Geographical Statistical Dictionary of the Amur and Primorye Regions, 1894). They performed economic functions, providing all the necessary focus centers that had arisen earlier. This arrangement of the territorial structure nodal element placement had an aerial-nuclear direction.

A similar model of a frame structure development was observed by a regular communication establishing between Odessa and Vladivostok. The only difference is that the development of the frame structure originated from the coast. The centers-focuses of economic and industrial orientation were built there (Geographical Statistical Dictionary of the Amur and Primorye Regions, 1894). The formation and development of the territorial structure nodal elements was very slow, the main reason was the lack and low quality of transport communications. The transport problem contributed to the adoption of political decisions by the authorities in the field of the territorial structure linear element formation and development (Highest Message Announced by the Governor of The Ministry of Finance, 2006).

The construction of highways in the South of the Far East was carried out in those areas that were of economic, political and strategic importance for Russia connecting important nodal elements of the territorial structure from the point of view of economic and geographical location: Blagoveshchensk, Khabarovsk, Vladivostok - the Ussuriyskaya railway; Verkhneudinsk (Ulan-Ude), Chita, Pogranichny, Mukden, Vladivostok - East China road; Vladivostok, Mukden, Dalny, Port Arthur - South Manchurian road (Kovalchuk, 1997). The large-scale construction of linear elements of the territorial structure in the region began with the construction of the Ussuriyskaya highway. Throughout its course, industrial focus centers arose (Geographical Statistical Dictionary of the Amur and Primorye Regions, 1894). Initially, the line had only local significance, which was explained by its isolation from the all-Russian railway network. The problem might have been overcome with the help of a developed system of transport communications (Personal Highest Decree Given To The Ministry Of Railways, 2007).

According to the economist and politician A. Brooks, the main way to solve it could be "a grandiose transcontinental railway construction with an end point in Port Arthur and Qingdao (Dalny port)" (Haushofer, 2001). Its practical result was the construction of geostrategic communication lines (Sanachev et al., 2006), performing the function of a geopolitical attraction of territories that are unique in their characteristics - Manchuria and the Kwantung Peninsula. So, observing S.Yu. Witte's "principle of the integrity of the Chinese empire" they managed to build linear elements of the territorial structure: the Chinese-Eastern and South-Manchurian 
railways (Tarle, 2001). Throughout their entire length, industrial focus centers arose: Harbin, Pogranichnaya station, Manchuria, Port Arthur, Dalny, Mugden (Haushofer, 2001).

This is how a single geostrategic communication network was formed from Chelyabinsk to Khabarovsk, which did not last long. Confrontational relations with the Qing empire and Japan led the government to consider the initial version of laying a steel track across the territory of the Russian state from Chita to Vladivostok, with the branch to Blagoveshchensk - the Amur railway (Highly Approved Regulations of the Council of Ministers, 2006). The implementation of the state policy of large-scale construction of linear elements of the territorial structure by government "taking into account the logic of key geostrategic points" (Sanachev et al., 2006) contributed to the formation of a linear areal-nodal - linear-nodal polycentric frame structure characterized by the development of linear elements of the territorial structure, which became the impetus for the emergence and growth of nodal ones.

Political and economic events unfolding in the south of the Far East during 1918-1922 and during 1922-1939 were aimed at elimination the consequences of a conflict of interests of a territorial nature. Here, the bodies of the autonomous economic management have oriented the economy of the south of the region towards the extraction and exploitation of their own resources in order to solve financial and raw material problems. This government decision contributed to the widespread emergence of industrial focus centers. Their dispersed arrangement over the southern territory of the region contributed to the further development of its areal space. Such a model had an aerial-nodal direction of the frame structure development, ensuring it's branching in breadth.

Further formation and ramification of the territorial structure and its elements was accompanied by the influence of internal and external economic and political realities occurring in Soviet times. The industries related to the country defense capability improvement have undergone transformations (Telegram, 2008; Information of the Secretary of the Khabarovsk City Committee of The Cpsu, 2008). Focusing on the maximum development of industries and means of production, the government acts as a powerful factor in the development of territorial structures, the formation of which was accompanied by the ubiquitous emergence of focus centers mainly focused on raw materials.

The militarization of non-priority sectors of production took place on the territory of the Russian Far East south, which led to the maximum development of the defense industries, and the evacuation of factories from the western regions of the country (Minakir, 1995). Large-scale development and unlimited mining during the Second World War led to the ubiquitous emergence of focus centers. Along with their creation, the 
Elena S. Koshevaya, Tatyana K. Miroshnikova

reverse process was observed. The working village with the development of the deposit and with the absence of other industries was deprived of the able-bodied population, gradually turning into "dying" area.

Since the beginning of the 6o-ies, the role of extractive industries has declined. The priority place was taken by the service industries. The innovations carried out by the government since 1965-1985, represented the policy of an extensive path of development of agriculture and resources, especially fuel and energy, provided the formation of a ramified support frame in the south of the region in breadth due to the areal elements of the territorial structure. Based on the already created linear areal-nodal, linearnodal models of the polycentric frame structure, further transformation and formation of the support frame was carried out.

With the collapse of Soviet Russia, the priority course of the government regional policy at the end of the 20th century was the restoration and formation of various types of relations with the countries of the Asia-Pacific region, which was carried out in a number of areas: raw materials, forestry, fishing, tourism, migration, transport. State policy for the implementation of integration trends during 1990-2008 contributed to the functional expansion of focus centers - industrial centers: Blagoveshchensk, Khabarovsk, Vladivostok, Ussuriisk, Pogranichny, and Grodekovo.

According to M.Yu. Shinkovsky, these centers are capable to act as the "vents" (Shinkovsky, 2004) of close border cooperation. On this basis, the creation of special forms of economic interaction in the border zone has acquired particular urgency. The models of zonal (focal) and "open rationalism" of cooperation were formed here. Based on these models, border trade complexes were created and operated in Manchuria and the Primorsky Territory within the Pogranichny - Suifunhe region, and the Amur area in the Blagoveshchensk - Heihe region.

The basis for the development of industrial centers of the frame structure within the territorial structure of the Russian south of the Far East during the period 1990-2008 was the production of competitive products - high technologies. So, the production of water treatment plants was actively carried out at the enterprises of the innovative orientation of the Vladivostok, Komsomolsk-on-Amur, and Khabarovsk (Levinthal, 2004). The transformations carried out had an insignificant effect on the process of the frame structure areal-nodal model restoration in the south of the region. Its further development was carried out through the construction and improvement of the territorial structure linear elements.

Infrastructure development was recognized as the main trend of further cross-border cooperation of Russia from 2004 to 2012. The transport problem hindered the implementation of the integration policy and the further development of the nodal and areal elements. The lack of an efficient 
transport system, primarily trunk pipelines, was a constraining factor in expansion the ties with the APR country. So from 2004 to 2010 after the implementation of transport cooperation policy, the linear elements of the system were developed - the Sakhalin - Komsomolsk-on-Amur Khabarovsk gas pipeline; the Chayvo - De-Kastri oil pipeline, the Eastern Siberia - Pacific Ocean oil pipeline (Levinthal, 2004).

Their formation had a significant impact on the development of the areal space in the south of the region through the formation of linear elements and the emergence of focus centers along their entire length, and also through the formation and development of highways. Here, according to Uyanov S.V., the priority was intermodal (Ulanov, 2007) container transportation. The most frequent traffic was along the Harbin - Vladivostok, Mudanjiang - Ussuriisk highways.

Further functioning of the areal-nodal and areal-linear polycentric models of the supporting frame of the year was carried out within the framework of the following target programs and the strategies for the Far East development developed by the government: "Socio-economic development of the Far East and the Trans-Baikal region until 2025"; Transport strategy of Russia until 2030; The strategy for the development of railway transport in Russia until 2030; the federal law "On the territories of advanced social and economic development in the Russian Federation". Here, the following elements of the territorial structure had the greatest economic development and functioning during 2013-2019: The nodal elements - Vladivostok - as a free port, Svobodny - the key center for the construction of a number of the largest high-tech enterprises for gas processing and gas chemistry; Komsomolsk-on-Amur is a dynamic center with the prospect of a modern high-tech industry development.

The areal elements, the functional growth of which was due to the creation of the territories of advanced socio-economic development (TAD), with a different typological direction: "Nadezhdinskaya" (light and food industries, diversified production and logistics, Primorsky Krai); Komsomolsk (industrial focus, Khabarovsk Territory); "Belogorsk" (agro-industrial focus, Amur region); "Mikhailovsky" (agricultural trend, Primorsky Territory), "Bolshoy Kamen" (industrial focus, shipbuilding, Primorsky Territory); "Petrochemical" (petrochemical focus, Primorsky Krai) (Eastern economic forum. Territories of advanced development, program, 2017).

The linear elements, their development for the most part occurred due to the growth of transport, information and communication infrastructure in $\mathrm{TAD}$, and the general development potential of localized territories. These are the functioning of the Power of Siberia gas transmission system route and the formation of the free port of Vladivostok, which includes the key ports in the south of the Far East: Zarubino, Nakhodka and Knevichi 
Elena S. Koshevaya, Tatyana K. Miroshnikova

Economic and Political Realities and Models of Territorial Structure Development in the South

airport and the presence of active promising large international transport corridors, such as "Primorye-1" and "Primorye-2" (Eastern economic forum. Territories of advanced development, program, 2017).

\section{Results}

After internal and external political and economic realities, transformations, and modernizations a linear arial-nodal - linear-nodal polycentric frame structure was formed in the south of the Far East. Its organization from 1860 to 2004 began with the formation of the arealnodal model. Further development of the support frame (from 2004 to 2018) continued with the development of the areal-linear model. From 2012 to 2019, it was carried out through the formation and development of industrial parks and clusters of various typologies on the basis of advanced development territories. Their formation contributed to the development of both models of the support frame - areal-nodal and areallinear (Baklanov, 2014). Within their borders, small and medium-sized cities, closely interacting with each other in all spheres of their life, acted as urban polycentric systems (Baklanov, 2014; Osipov and Krasova, 2017). According to P.Ya. Baklanov, they are destined to become "an impulse for the development of neighboring territories, i.e. have a multiplicative territorial effect".

\section{Bibliographic References}

ARTEMEV, Aleksandr. 1998. “Construction of cities and prisons of Transbaikalia and the Amur region in the second half of the XVII - XVIII century and types of fortifications" In: National history. No. 5, p. 140.

BAKLANOV, Petr. 2014. "Territories of advanced development: concept, structure, approaches to allocation" In: Regional studies. No. 3, p. 17.

EASTERN ECONOMIC FORUM. TERRITORIES OF ADVANCED DEVELOPMENT, PROGRAM. 2017. Available online. In: https:// forumvostok.ru/about/asez/. Consultation date: 06/03/2020.

GEOGRAPHICAL STATISTICAL DICTIONARY OF THE AMUR AND PRIMORYE REGIONS. 1894. Kirillov. O. D. Mokits. Blagoveshchensk, Russia. 
HAUSHOFER, Karl. 2001. Geopolitics. Works of different years. Kazan Federal University. Volga Region, Russia.

HIGHEST MESSAGE ANNOUNCED BY THE GOVERNOR OF THE MINISTRY OF FINANCE (SOBR. Decree of 1893 January 1, article 2). 2006. On the procedure and methods of construction of the great Siberian railway from December 10, 1892 / / the far East of Russia in the materials of legislation. 1890-1895-Vladivostok: Russian state historical archive of the Far East, No. 75, pp. 126-129.

HIGHLY APPROVED REGULATIONS OF THE COUNCIL OF MINISTERS (SOBR. Decree. 1907, October 30, ot. I, article 1292). 2006. On approving the construction cost of the head section of the West Amur railway from the Nerchinsk station on September 19, 1907 / / Far East of Russia in the materials of legislation. 1881-1889-Vladivostok: Russian state historical archive of the Far East, No. 47, pp. 120-121.

INFORMATION OF THE SECRETARY OF THE KHABAROVSK CITY COMMITTEE OF THE CPSU (b) Demkin I. N. about the release of ammunition at the factories of Khabarovsk, sent to the Secretary of the Khabarovsk regional Committee of the CPSU (b) Borkov G. A. 2008. // Khabarovsk. Pages of history: Collection of documents of the state archive of the Khabarovsk territory, the Russian state archive of the Far East about the history of the city of Khabarovsk. - Khabarovsk: Private collection. No. 119 - p. 145.

KOVALCHUK, Mikhail. 1997. History of transport in the far East of Russia (the second half of the XIX century. June 1941). Book 2. Historical aspects of transport development of the region. Priamurskoe geographical society Khabarovsk, Russia.

LEVINTHAL, Aropt. 2004. "Russian Far East. Development of foreign economic relations in the Russian Far East: problems and prospects" In: Problems of the Far East, 2004, No. 2, p. 68.

MINAKIR, Pavel. 1995. The Russian Far East: economic review. RIOTYPE. Khabarovsk, Russia.

OSIPOV, Viktor; KRASOVA, Elena. 2017. «Modern specialization of industry in cities of the Russian Far East: Innovation factor of dynamics» In: Revista ESPACIOS. Vol. 38, No. 62.

PERSONAL HIGHEST DECREE GIVEN TO THE MINISTRY OF RAILWAYS (SOBR. Decree of 1898, June 19, article 930), 2007. On alienation of land and property required for the construction of railway lines from the TRANS-Baikal and Ussuri Railways to the end points of the East 
Elena S. Koshevaya, Tatyana K. Miroshnikova

Economic and Political Realities and Models of Territorial Structure Development in the South

China railway from June 1, 1897 / / Far East of Russia in the materials of legislation. 1896-19899-Vladivostok: Russian state historical archive of the Far East.

SANACHEV, Iillda; SHINKOVSKY, Mikhail; BURLAKOV, Valdemi; PROKHOROV, Villimor. 2006. Naval power as a factor of geopolitics in the Asia-Pacific region. Monograph (Unpublished).

SHINKOVSKY, Mikhail. 2004. "Panorama of political science of Russia: the Far East. Cross-border cooperation as a lever for the development of the Russian Far East” In: Polis. No. 5, pp. 62-70.

SHINKOVSKY, Mikhail; SHVEDOV Vladlen; VOLYNCHUK, Andrei. 2007. "Geopolitical development of Northern pacifics (experience of system analysis): monograph" In: Dalnauka: Vladivostok, p. 60.

SHVEDOV, Vladlen G. 2006. Historical political geography: overview of formation, theoretical foundations, practice. Dalnauka. Vladivostok, Russia.

TARLE, Evgenij. 2001. Politika: istoriya territorialnykh uspatovat XV-XX century: essays. EKSMO-Press. Moscow, Russia.

TELEGRAM, 2008. the chief inspector of people's Commissariat of state control of the USSR in the Khabarovsk region Kostina on the implementation of the production plan the main defense products plant named after Molotov, sent to the people's Commissar of state control of the USSR Popov // Khabarovsk. Pages of history: Collection of documents of the state archive of the Khabarovsk territory, the Russian state archive of the Far East about the history of the city of Khabarovsk. - Khabarovsk: Private collection, No. 118.

ULANOV, Samol. 2007. "Transportation routes in Asia: implications for Russia, China and India" In: Problems of the Far East, No. 2, pp. 27-39.

ZAUSAEV, Vadim; LEDENEV, Mikhail; BYSTRITSKY; Shahib. 1995. Russian far East: answers to new challenges. Available online. In: http:// megaregion.narod.ru/articles_text_13.htm. Consultation date: 25/06/2020. 


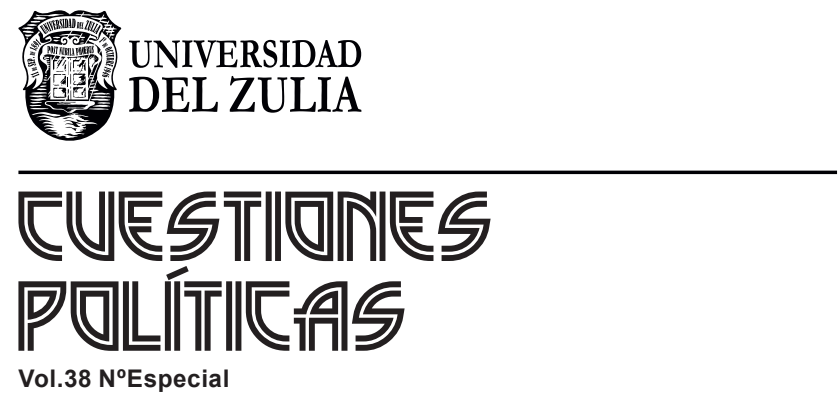

www.luz.edu.ve 